\title{
Challenges, Opportunities and Implementations of Building Effective Education Critical Mass Organization for Cooperative Learning: The Case of DMCTE
}

\author{
Atalay Mesfin Anteneh \\ Debremarkos College of Teacher Education \\ Department of Aesthetic\& physical education \\ Po.box -428 \\ Ethiopia
}

\begin{abstract}
The main purpose of this study was to assess and analyze challenges, opportunities and implementing of effective education critical mass organization for cooperative learning at Debremarkos College of teacher education. To achieve this objective a descriptive survey method was employed. The data for the study were collected by quantitative and qualitative methods. Open ended and closed ended questionnaires were distributed and collected back (199 students and 30 college teachers). FGD were also employed with five academic commission members. The data collected with the above listed data collection instruments were analyzed by using both qualitative and quantitative method of data analysis. Due to the nature of data collected from the participants, frequency, percentage, mean, one way ANOVA, one sample T-test and post hock were used for analyzing the collected data.FGD and open ended questionnaire data were analyzed qualitatively like narration interpretation and direct citation. After analyzing the collected data, the main challenges for organizing and implementing effective education critical mass were negative attitude of teachers and students towards the program, students belief of the task is belongs to only teachers, no guide line for the implementation, class size and lack of time were the main challenges. Some opportunities like having experienced advisor, the college write a formal letter for the assigned advisor and having enough space at the college were best opportunities. The level of implementation at the college was at grass root level but there were significant difference between departments, student understanding and students' attitude towards the program. Finally, based on the conclusion driven from collected and analyzed data recommendations were forwarded to different stakeholders who are directly or indirectly participate in the program like students, teachers, regional education bureau, college administrative bodies and academic commission were taken lion share recommendations.
\end{abstract}

\section{Keywords}

Critical Mass, Cooperative Learning, Attitude, Organizing and Implementing.

\section{INTRODUCTION}

A central concept in organizing and implementing effective critical mass in education is the concept of "critical masses. It is frequently invoked to explain why students do not always achieve the minimum learning standard competency to represent students once they are in class. Gender and politics scholars and activists suggest that this pattern is due not to the inclinations of only graduate teachers, but rather to the fact that there are many problems in student's knowledge. Attitude and skill compared with the expected outcome Wasley (2006).The concept of effective education critical mass has not only been applied sparingly to the field of educational organization. However, in those instances when it has been used as a framework, definite results have been found.

Teaching and learning in education are changing. Active learning has become an important focus in this time of pedagogical change supporting with effective education critical mass. While the term encompasses a broad array of practices, collaborative learning, or small group work, remains an important element of active learning theory and practice. Research suggests that students learn best when they are actively involved in the process (Davis, 1993). Studies have shown a variety of groupings, the frequency of use of each type of grouping has changed over the last twenty years, with increases in whole class groupings and small groups' contexts for teaching - but with an emphasis remaining on individual work. Effective education critical mass is used as the base for implementing collaborative learning in classroom situation.

\subsection{Statements of the Problem}

The debate on 'critical mass' in education and politics research can be traced back to three influential works, two by Kanter (1977a; 1977b) and one by Dahlerup(1988), which, respectively, analyze the experiences of implementing effective critical mass form small minorities in the corporate and political spheres. Although both authors are concerned primarily with how effective critical mass responded with different groups in corporate and political aspect, These latter ideas form the nucleus of the critical mass concept as it has been taken up by subsequent researchers, who have in turn transformed the possibilities signaled by Kanter and Dahlerup into firmer expectations about the behavior of effective critical mass, which we label 'critical mass theory'. To separate their contributions from these later interpretations, the researcher read the arguments of Kanter and Dahlerup to establish the precise research gap. Mean while above listed researchers researched in the concept of critical mass, the researcher did not found researches with challenges, opportunities and implementation of effective critical mass in education organization. Due to this reason the researcher wants to conduct research on this topic of research.

Cooperative learning is a successful teaching strategy in which small teams, each with students of different levels of ability, use a variety of learning activities to improve their understanding of a subject. Each member of a team is responsible not only for learning what is taught but also for 
helping teammates learn, thus creating an atmosphere of achievement. Debremarkos College of teacher education is one of the institutions which need to organize, implement and practice effective education critical mass at class level. Due to this reason the following research question were raised:

1. What are the challenges that influence the building effective education critical mass organization to motivate cooperative learning?

2. What opportunities provided for teachers and students for using effective education critical mass organization for cooperative learning?

3. To what extent effective education critical masses organize and implement in line with cooperative learning?

4. Is there a significant difference between departments in organizing and implementing effective critical mass organization at DMCTE?

\subsection{Objective of the study}

The main objective of this study was searching about challenges, opportunities and implementation of critical mass organization for cooperative learning and indentifywether there is significant difference between different departments in organizing and implementing effective critical mass organization for cooperative learning.

In line with the above general objective of the study, the following specific objectives were designed.

To find out the challenges of building effective education critical mass organization to motivate cooperative learning.

Asses the opportunities of teachers and students for implementing and organizing effective education critical mass for cooperative learning.

Find out that to what extent effective education critical mass organized and implemented in line with cooperative learning.

To check about whether there are significant difference in organizing and implementing effective critical mass for cooperative learning between different departments.

\subsection{Significance of the Study}

This study has supreme importance by identifying challenges, opportunities and implementation of effective critical mass organization for cooperative learning to students, teachers, Debremarkos College of teacher education and Regional education office will be beneficiaries of this study. Specifically, the findings of the study have the following contributions:

The research result assists DMCTE teachers and students by identifying problems on organizing and implementing effective critical mass organization for cooperative learning.

The evidence may help to fill an information gap that exists on organizing and implementing effective critical mass organization for cooperative learning.

Knowledge about those factors, which may influence on the actual process of organizing and implementing effective critical mass organization for cooperative learning would generally encourage the teachers students and other stakeholders to respond appropriately in order to organize and implement effective critical mass organization for cooperative learning.

It can also help to go up with best organization implementation and relating of effective critical mass organization to other colleges where effective critical mass organization practice is going on.

Finally, based on the conclusions drawn in this research, scholars from different fields of study may use them as a spring board for further studies.

\subsection{Conceptual Framework of the Study}

A well organizing and implementation of effective education critical mass participation is an important instrument for best learning outcome for higher education courses (Elgort, Smith \&Toland, 2008). Although many students feel as though they can accomplish assignments better by in group rather than themselves, instructors find that group work helps the students apply knowledge (Elgort, Smith\&Toland, 2008). However, merely assigning a group does not itself create critical thinking outcomes. Therefore, the instructor must be cognizant of how best to facilitate effective collaborative learning environments through organizing and using effective education critical mass.1.5.1. Relation between Effective Critical Mass and Active Learning

As one endiginiouse researcher write in his research work," Research results and the researchers experience indicate that students learn best when they participate in learning [Animaw; 2012]"

The above two best ideas magnify about the strong relationship between effective critical mass and students result. Meanwhile when the students well organized and supported with effective critical mass organization the best become in their expected achievements. The following picture strengthen about the importance of collaborative learning with forming education critical mass The above picture deals with group learning and cooperative learning through organizing effective education critical mass in educationSmith and McGregor (1992).

\subsection{Delimitation of the Study}

Area wise delimitation: - The study was delimited at Debremarkos College of teachers' education Participant wise delimitation: - In participant aspects the study was delimited at 2nd year students and teachers of Debremarkos College of teachers' education.

Content wise delimitation: - The content delimitation of the study was about challenges, opportunities and implementation of effective critical mass organization

\section{RESEARCH METHODOLOGY}

A descriptive survey method was employed for this study. The researcher has chosen this method mainly because it is an appropriate method to explore or investigate challenges, opportunities and implementation of effective education critical mass. Besides, the method would be appropriate to describe what is happening in real implementation and organizing effective education critical mass, practice and gathering the necessary information from the selected samples about challenges and opportunities.

\subsection{Research Setting}

The researcher conducted his study at Debremarkos College of teacher education. The researcher selected this college because of his familiarity with the college teachers and students. And also the researcher knows about this college. This made the researcher to be hopeful to collect the required data. The researcher selected DMCTE because this college is 
near for conducting the research for the researcher and easily collects reliable data.

\subsection{Subject of the Study}

The study populations were both students and teachers during the data collection period. Currently the college (DMCTE) has-107 teachers and 535 2nd year students. Among these302 are male and 233 are female.

The data for this study were collected from teachers and students of Debremarkos College of teacher education. The sample size of the participants includes 30 from teachers [ 27 male and 3 female] and 199 [115 male and 84 female] from students. A total number of 229 [87 Female and 112 male] were participants during this study.

\subsection{Sampling Techniques and Sample size of the study}

Teachers and students were chosen using simple random sampling technique. The researcher used this technique because it gives equal chance of being involved in the sample of the study. For the focuses group discussion, the researcher used purposive sampling technique in which the selected

Samples are expected to react the raised questions well; two ranked students were selected from each class.

\subsection{Method of Data Collection}

The required data for this study were obtained from teachers and students through questionnaire, FGD, document analysis and observation in line with objective of the study.

The researcher used four types of data collection instruments to gather data of this study. Namely questionnaire, FGD, document analysis and observation were used.

The researcher has chosen this instrument because it is a quick way of gathering data and it can reach a large number of subjects and it is widely used in most educational researches (Koul, 1984). Two questionnaires were designed for both teachers and students. Both the questionnaires were designed in English and include both open ended closed-ended questions and distributed to the teachers who were selected as sample unit from different departments.

The students' questionnaire was designed in English as it is stated above, but it was translated into Amharic as it was assumed that most students were more proficient in Amharic than they were in English. This was purposely done to avoid the problem of language hindrance which can interfere with obtaining reliable data. Then, together version was commented by one professional teacher and two English language teachers to cheek the face validity and pilot tested in objective groups which were notincluded into the sample units. Accordingly, the reliability statistics (Crombach alpha) for teachers' questionnaire and was 0.92 and 0.97 for students questionnaires. Finally, the questionnaire was improved and administered in person. The questionnaires' were distributed and collected back with the researcher himself.

The researcher made observation in order to obtain data which reflect the challenges, opportunities and implementation of effective education critical mass for cooperative learning. The researcher believed that making observation before, administering questionnaires would relatively minimize the tendency of teachers and students to change their real challenges, opportunities and implementation of effective education critical mass at college. According to Kumar (1996), observation is a feasible tool when we are interested in assessing what the real situation is. So the researcher has been made observation four consecutive days in different sections.The document analysis was done at all six departments with the prepared checklists. Different student's reports, teacher reports and department minutes were observed and analyzed well in order to reach at aright conclusion. Finally the academic commission minutes also observed and crosschecking with other data obtained with different data collection instruments.

\subsection{Data Collection Procedure}

Before administering, the questionnaire was piloted in a small group of 42 first year students at DMCTE which was not the research site of this study. The questionnaire was taken to professional teacher and two English teachers for comments. Based on the comments given some improvement was made and the number of question was reduced in number due to their appropriateness.

To collect adequate data from the subject of the study, questioner FGD, document analysis and observation were advisable data collection tools. Then, first, the purpose and importance of the research was explained to the subject of the study briefly. The researcher administered the questionnaires and collects them back face to face. As a result there was $100 \%$ return rate mean all distributed questionnaires were collected back.

The objective of the analysis is for drawing important conclusions about challenges, opportunities and implementation of effective critical mass for cooperative learning. Based on the data collected from the participants. The data was analyzed depending on the nature of the data collected. After the raw data were collected it was analyzed with both qualitative and quantitative analysis. The researcher used narration, interpretation and direct citations from qualitative data analysis and frequency, percentage, one way ANOVA, one sample t-test and correlation were used from quantitative data analysis techniques. The data obtained from FGD and observation was analyzed through narration, direct quotation and interpretation.

The researcher worried about all the ethical consideration when conducting the study. The following main points were discussed and informed to the participants for avoiding frustration and developing honesty between the researcher and the respondents.

At the beginning of the questionnaire, the researcher introduces himself and why he needs the data and how he used.

The researcher did not needed their name because he only needs the data from the participants and he did not care about by whom fill the questionnaire if selected as participants of the study.

The researcher informed to the participants about the importance of giving real information to reach in aright conclusion

\section{DATA ANALYSES AND INTERPRETATION}

In this section, the data collected using dissimilar instruments are to be had and interpreted in line with the research questions sequenced in chapter one. As a result, the themes under which the analysis focused are: demographic characteristics of respondents, challenges, opportunities and implementation of effective critical mass organization for 
cooperative learning. The variation of effective education critical mass organization across departments was also analyzed

As made known above respondents provided data on dissimilar demographic variables mainly for three basic reasons: to get better the quality of the data for assessing the organization and implementation of effective critical mass for cooperative learning, to accept or reject the data which isn't meet during triangulation and to consider some of the variables to test statistical significance. Hence, respondents from both sexes, different age category, educational background, year of advising experience and assigning as an advisor had provided data to the study. For that reason, majority of the teachers and students respondents were males. With respect to their level of education, majority of the teachers having MSc and Med degree and most students were grade ten completes. Age wise, about $70 \%$ of the teachers were in between the age of 30-40 mean they perform activities well and all of the sample students were found in the very productive age, 20-30. In addition, in their experience of running advising all the entire selected sample teachers were assigned as an advisor.

\subsection{Challenges faced for organizing and implementing effective critical mass organization for cooperative learning.}

The researcher found striking about students' attitude towards effective critical mass organization was nonchalance. On the other hand some students were to be involved in effective critical mass organization for only the purpose of gaining mark with the help of best performer students.

The highest development of students mind must be possible without gaining knowledge in cooperative learning (Igorstravisky, 1972). This task should be lead with the intensive consultation between departments, advisor teachers and advisee students. But some teachers themselves viewed a group is an effective critical mass organization in their classroom situation.

The strength of group affiliation can vary widely. It may be no causal joining of students grouping what they shared single shard interest just sharing marks from other cleaver students (Sharan.1987)

Two things were stand out clearly from the collected data. The first contributor for the poor implementation or major challenges were students attitude and the second challenge were the attitude of teachers towards organizing and implementing of effective critical mass for cooperative learning in their assigned class. In fact the contribution of effective critical mass was shining out in some specific class in relation with their grade achievement. The following tables FGDs and questionnaires were used to strengthen the above listed challenges.

Likewise, the result obtained from FGD data complement the statistical data portrayed in concerning the implementation of organizing implementing effective critical mass for cooperative learning. FGD discussion assured that although teachers are interested to organize and implement effective critical mass organization for cooperative learning they had limitations like believe that the organization is related with politics, ask extra time and complaining about student's interest about organizing and implementing effective critical mass for cooperative learning.

The ACM1 respond summed up as follows:

The college has been given different support for teachers on how to carry out the task of organizing and implementing effective critical mass organization for cooperative learning. However, the support isn't becoming fruit full because different reports assured that organizing effective critical mass is found at infant stage. Mostly this problem comes from lack of commitments from teachers.

Other ACM2 also support this idea as follows.

Our college tries many mechanisms for the best implementation of effective critical mass like assigning teachers by writing letters having reference number, assigning professional department teachers as leaders of effective critical mass organization and including this activity as criteria of teachers efficiency but still this task isn't performed well. As some teachers complain, they are occupied with other routine tasks. Other teachers also complaining about that since they are assigned at extension program, students aren't volunteer to participate with in effective critical mass organization.

\section{$\mathrm{ACM} 3$}

When the regional education office supervision team deals with students, they have witnessed about the poor implementation of effective critical mass organization in our college. And the academic commission takes a stand to perform best in the future time.

Table 1 Teacher's response for open ended questionnaire Related with challenges.

Teachers have been responded about the challegenes face during organization and implementation effective critical mass organization for cooperative learning in three perspectives like;

\begin{tabular}{|c|c|c|}
\hline Challenges related to Teachers & $\begin{array}{c}\text { challenges related with the } \\
\text { college }\end{array}$ & challenges related with students \\
\hline $\begin{array}{l}\text { Teacher believe only organizing is } \\
\text { their task. }\end{array}$ & Lack of awareness creation & $\begin{array}{l}\text { Cleaver students believed that studying with one to } \\
\text { five organizations is killing time. }\end{array}$ \\
\hline $\begin{array}{l}\text { Teachers face } \\
\text { cleaver students }\end{array}$ & Lack of time to follow-up students & $\begin{array}{l}\text { Most students come up with their mobiles and open } \\
\text { music instead of studying with group. }\end{array}$ \\
\hline $\begin{array}{l}\text { Other teachers give assignment in } \\
\text { different groups. }\end{array}$ & $\begin{array}{l}\text { The college only write letter but it } \\
\text { lacks support }\end{array}$ & It becomes a means of conflict \\
\hline Most teachers used static grouping & $\begin{array}{l}\text { Even if the college management } \\
\text { take as the major responsibility, it }\end{array}$ & Students think leading effective critical mass is only \\
\hline
\end{tabular}




\begin{tabular}{l|l|l}
\hline in different semester. & lacks follow-up teachers activities & $\begin{array}{l}\text { the task of teachers. } \\
\text { Overlapping of tasks like practicum. }\end{array}$ \\
\hline $\begin{array}{l}\text { Teachers associate effective critical } \\
\text { mass organization with politics. }\end{array}$ & $\begin{array}{l}\text { No guide lines about the } \\
\text { implementation of effective critical } \\
\text { mass organization at college level. }\end{array}$ & Lack of awareness about the organization \\
\hline $\begin{array}{l}\text { Most teachers believed that only } \\
\text { putting signature during registration } \\
\text { time is the only task. }\end{array}$ & & $\begin{array}{l}\text { Students did not use show conviction to use effective } \\
\text { critical mass for their better learning. }\end{array}$ \\
\hline
\end{tabular}

Students are expected to prepared sufficiently for skills in group process; students will experience the process of group work itself as highly rewarding...never grade or evaluate students on their individual contributions to the group product." (Diaz \& Yang, 2005) work, as well as that of Dahlerup(1988) but students in the study area were come upping with their mobile to disturb others, they need only the output mean grade without studying, they consider that the task of leading and organizing effective critical mass is only the task of teachers. Generally the situation which existed in the study area were contradicts with the literature.

From a motivation list perspective (e.g., Johnson \& Johnson, 1992; Slavin, 1983a, b, 1995), cooperative incentive structures create a situation in which the only way group members can attain their own personal goals is if the group is successful. Therefore, to meet their personal goals, group members must both help their group mates to do whatever helps the group to succeed, and, perhaps even more importantly, to encourage their group mates to exert maximum efforts but the students in the study area were thinking about studying alone is best and helping each other or cooperative learning is time consuming for them. In this regard, anyone can understand from students saying that they have attitude problem.

A hall mark of the social cohesion perspective is an emphasis on teambuilding activities in preparation for cooperative learning, and processing or group self-evaluation during and after group activities. Social cohesion theorists tend to downplay or reject the group incentives and individual accountability held by motivation list researchers to be essential. For example, Cohen (1986, pp. 69-70) in line with this, the data collected from participants of the study assured that students of the study area were against self evaluation in effective critical mass for cooperative learning.

\subsection{Students saying on challenges of implementing effective critical mass organization for cooperative learning.}

In addition to closed ended questionnaire, students were invited to fill open ended questionnaire. In this regard students were generated amazing and impressed ideas.

Other student responded that even he doesn't know who is his advisor is and when reresponded about one to five organization, we have many one to five organizations which are organized by different teachers for assignment purpose. Generally students response have the same with document analysis results mean while teachers are careless for effective critical mass organization and they did not support them.
Instead of supporting them, they let them to organize by themselves and ask them a report.

One best performer students write the following ideas, illustrated teacher's response on different challenges which is an obstacle for organizing and implementing effective critical mass organization for cooperative learning. Even if the above table shows about different challenges, the following were the main challenges teachers responded. Number of students per class, student's attitude, students' preference of study habit, complains of cleaver students and the problem of relating effective critical mass in line with the field of education were challenges observed.

Many Literature on suitable organization and implementation of effective critical mass organization advocate the well positive attitude for something doing by him/her whole hearted commitment and team spirit for implementing what educators supported related with cooperative learning. Case in point, educa.ion is vital to modify peoples' knowledge, attitude and skills (Mangal, 2009; Curtis, 2003). This implies that classroom leaders who lacked the necessary knowledge, skill and attitude might not properly organize and implement effective critical mass organization for cooperative learning.

By means of commitment, organizing and implementation of effective critical mass organization for cooperative learning should be a day-to-day activities of teachers who are assigned as advisor. Effective education critical mass organization is not expected as completed within a day or month rather it needs contentious follow up of the leaders.

This is because the central idea of organizing and implementing effective critical mass organization for cooperative learning is the way of making tangible changes on a regular basis namely always improving students result, knowledge, skill, attitude and effectiveness in their field of study. Then, the proper organization and implementation of effective critical mass for cooperative learning needs wholehearted commitment.

All the above responses which were responded from Academic commission FGD member support the student's idea. But teachers responses weren't match that much with this data. Then the data triangulation was use full for reaching conclusion that rejects the teacher response somewhat. In sum, teachers point out that there were major challenges that effect the full implementation of organizing and implementing effective critical mass organization for cooperative learning. The following ideas were paraphrased from the response of teachers for open ended questions. Some of them were: 
Teachers related challenges such as absence of dutifulness, lack of commitment, wrong perception of teachers towards the task.

Students related challenges such as problem of understanding, believing as the task of teachers used as routine task and unwillingness of coming in the studding program. Extension program students weren't present at the arranged time.

Difficulty of interrelation between teachers and students such as sense of sabotage on students and lack of understanding about the relationship between effective critical mass organization and cooperative learning.

Situation related problems such as lack of working time which is teachers are on different tasks like practicum tasks.

Organizational related problems such as assigning teachers more than one class which are out of the class they are thought. Absence of reinforcement mechanism for effective teachers in organizing and implementing effective critical mass organization for cooperative learning.
Be short of commitments in extension students because they are learning with support of themselves.

Some cleaver student's believed that helping others or cooperative learning is time consuming and they prefer to study with their friend rather than with the arranged group.

Therefore, poor level of the organizing and implementing of effective critical mass organization for cooperative learning, biased perceptions of the students and teachers on organizing and implementation of effective critical mass organization for cooperative learning, absence of positive relationship between teachers and students, lack of awareness on students about effective critical mass organization in relation with cooperative learning and lack of time to arrange studying time were the major challenges derived from the questionnaire and the FGD as well.

During the time of data collection period many teachers narrate different kinds of opportunities found at the college environment. The following table is used to sum up and emphasized teachers' response.

Table 2. Opportunities provided for teachers and students in organizing and implementing effective education critical mass organization for cooperative learning

\begin{tabular}{l|l|l}
\hline Opportunities related to Teachers & Opportunities related with the college & Opportunities related with students \\
\hline $\begin{array}{l}\text { Well experienced advisors were } \\
\text { available. }\end{array}$ & $\begin{array}{l}\text { The college tries to list the task of } \\
\text { teachers when they assigned as an } \\
\text { advisor. }\end{array}$ & Each section has their own advisor. \\
\hline $\begin{array}{l}\text { Presence of some active effective } \\
\text { critical mass organization in some } \\
\text { departments. }\end{array}$ & $\begin{array}{l}\text { The task is evaluated with academic } \\
\text { commission once in two week. }\end{array}$ & $\begin{array}{l}\text { The organization of effective critical mass is } \\
\text { used for doing assignments and dealing about } \\
\text { practicum presentation. }\end{array}$ \\
\hline $\begin{array}{l}\text { There are policy supports from the } \\
\text { government side. }\end{array}$ & $\begin{array}{l}\text { Make decision on assigning profession } \\
\text { department teachers in this task. }\end{array}$ & $\begin{array}{l}\text { Since this task was started at high school level, } \\
\text { students aren't stranger for effective critical } \\
\text { mass. }\end{array}$ \\
$\begin{array}{l}\text { The college commitment towards the } \\
\text { task by assigning teachers as an } \\
\text { advisor. }\end{array}$ & $\begin{array}{l}\text { Arrange discussion with students about } \\
\text { the implementation of this task. }\end{array}$ & $\begin{array}{l}\text { In some section there were some students who } \\
\text { have a facilitator skill. }\end{array}$ \\
\hline $\begin{array}{l}\text { The organization is supported by pre } \\
\text { service and in service case workers. }\end{array}$ & $\begin{array}{l}\text { Arranging extra classes in the opposite } \\
\text { shift to perform this task. }\end{array}$ & $\begin{array}{l}\text { Enough space for studying by using this } \\
\text { effective critical mass organization. }\end{array}$ \\
\hline $\begin{array}{l}\text { Having adequate member of teachers } \\
\text { to lead this organization. }\end{array}$ & \begin{tabular}{l}
. \\
\hline
\end{tabular}
\end{tabular}

Many educators suppose that there are solid insignificant situations which have to be meeting for successful organization and implementation of effective critical mass organization for cooperative learning (olso 1982) In this regard, Teachers and students were asked to extract the supposed opportunities of organizing and implementing effective critical mass organization for cooperative learning at Debremarkos College of Teacher Education. Accordingly, both teachers and students described that there are many opportunities for organizing and implementing critical mass organization for cooperative learning.

Even if there are many opportunities, In particular, the college's make an effort according to the participants responded the following responses were narrated by Teachers and students.
The help of Teachers, supervisors and head teachers core process case workers.

The college assigns Teachers officially with listing their tasks.

Incorporate participating in advising and organizing in the format of teacher's efficiency.

Approval of strategy on organizing and using effective critical mass organization for cooperative learning.

Orientation has been given for fresh students.

Assigning all teachers as an advisor

Considering students participation as normal class

There are an experienced advisor at the college Amazing data has been found. When compared the response of the teachers and students it has a big difference mean that the response of 
teachers seem exaggerated. Because of organizing and implementing effective critical mass for cooperative learning is a task done on students. Then, when teachers responded as organized and implemented but students complained that the organizing and implementing the action is dropped task. As seen from the tables above the average mean of teachers were 65.833 while the average mean of students response were 41.5.There is a 24.33 mean difference between teachers and students response.

Similarly, level organizing and using effective education critical mass for cooperative learning at Debremarkos College of teacher's education was researched to see whether or not there is implementation difference in organizing and implementing effective critical mass organization for cooperative learning. However, both teachers and student respondents who have different department, Years of advising experience and weekly work load respectively rate the level of organizing and implementing effective critical mass for cooperative learning. The organization and implementation level is almost different in department way where as almost in the same way in level of education and advising experience. In addition to the scales teachers and students filled in, they were also

asked to respond to general items that were related to organizing and implementing critical mass organization for cooperative learning at the study area on agree, strongly agree, disagree and strongly disagree format. Different reports were revealed. For instance, teachers reported that they were well versed with the government's strategy to organizing and implementing effective critical mass organization for cooperative learning have evaluated the effects of the support teachers had delivered starting from organizing and implementing effective critical mass organization for cooperative learning. Students also assured that when they were under the help of teachers support they practice effective critical mass organization in line with cooperative learning while the reverse is true.

On the other hand, they were also reported that Teachers lacked the commitment to organize and implement effective critical mass organization for cooperative learning. This implies that the response they provided on the organizing and implementing of effective critical mass organization for cooperative learning was simply a dividing of students and reporting for the department and then setting down. Moreover, the response of students assured that level of education isn't the determinant factor for organizing and implementing critical mass organization.

The one way analysisof variance displayed in revealed that there was a statistically significant difference in the organization and implementation of effective critical mass organization for cooperative learning between listed variables. There was significant difference in different departments, between different levels of understanding, different perception of teachers, student attitude, extra time teachers have, student attitude and interpretation of effective critical mass organization for cooperative learning. The following post hoc data analysis showed is used to strengthen the one-way analysis of variance.

Table-3: Post hoc comparison by level Departments

\begin{tabular}{|l|l|r|l|l|l|l|l|l|}
\hline No & Level & Mean & 1 & 2 & 3 & 4 & 5 & 6 \\
\hline 1 & Mathematics Department & 1.12 & - & & & & & \\
\hline 2 & Language Department & 1.68 & & - & - & & & \\
\hline 3 & Professional studies Department & 2.42 & & & - & & \\
\hline 4 & Social science Department & 3.18 & & & & & - & \\
\hline 5 & Natural science Department & 4.13 & & & & & & - \\
\hline 6 & Aesthetics and physical education Department & 6.52 & $*$ & $*$ & $*$ & $*$ & $*$ & \\
\hline
\end{tabular}

*the mean difference is significant at alpha level of 0.05

Table-4: Post hoc comparison by level of students understanding on effective critical mass organization

\begin{tabular}{|l|l|r|l|l|l|l|l|l|}
\hline No & Level & Mean & 1 & 2 & 3 & 4 & 5 & 6 \\
\hline 1 & Students who believe as the task of teachers & 1.68 & - & & & & & \\
\hline 2 & Students who are relating with politics & 2.01 & & - & & & \\
\hline 3 & Students want to study alone & 3.31 & & & - & & \\
\hline 4 & Students aimed to only gaining mark & 4.07 & & & & - & \\
\hline 5 & Natural science & 5.02 & & & & & - \\
\hline 6 & Students think as it is cooperative learning & 7.63 & $*$ & $*$ & $*$ & $*$ & $*$ & \\
\hline
\end{tabular}

*the mean difference is significant at alpha level of 0.05 
Table-5: Post hoc comparison by level student's attitude towards effective critical mass organization

\begin{tabular}{|l|l|r|l|l|l|l|}
\hline No & Level & Mean & 1 & 2 & 3 & 4 \\
\hline 1 & Students who didn't attend at arranged time & 2.24 & - & & & \\
\hline 2 & Students aimed to be dependent on cleaver one & 4.26 & & - & & \\
\hline 3 & Students attained for assignment purpose & 5.14 & & & - & \\
\hline 4 & Students who have positive attitude & 8.32 & $*$ & $*$ & $*$ & $*$ \\
\hline
\end{tabular}

\subsection{Data obtained from Document Analysis on implementation of effective critical mass organization for cooperative learning at the study area.}

The document analysis was takes place for checking the students report, teachers report and to see about what teachers and students response in relation with the report documented at the department level.

During document analysis the researcher have been used number of teacher reports per year and number of students report per year and also the researcher used the academic commission agendas about effective critical mass organization. Because all the department heads reported about the organization and implementation of effective critical mass for cooperative learning, assessing the commission agenda was a basic element for to what extent the saying of department is congruent with students report and teachers report to the department head.

All departments haven't the same status of organizing and implementing effective critical mass organization for cooperative learning. As the document analysis assured the implementation of effective critical mass organization for cooperative learning is Aesthetics and physical education, social science, language, mathematics, natural science and professional studies respectively from good implementation to poor as the researcher count the report documented at the department level. The documents analysis data were summarized with the following table

\section{SUMMERY, CONCLUSIONS AND RECOMMENDATIONS}

\subsection{Summery}

The main objective of this study aimed at challenges, opportunities and implementation of effective education critical mass for cooperative learning. Descriptive survey method was employed followed by different data collection instruments like questionnaire, FGD, observation and document analysis. After the data collected from the selected participants, interpretation, narration, direct citation, ANOVA,T-test and post hock data analysis were employed to assessed about challenges, opportunities and implementation of effective education critical mass for cooperative learning. The researcher summarizes the findings from the study conclusively as the research question sequenced. At Debremarkos College of teacher education, there are different challenges that hinder the implementation of the program at college level..

\subsection{Conclusions}

The study presented here extends the existing literature by providing observed data to support for the Critical Masstheory's application to education systems. Further, the present study highlights the challenges, opportunities and implementation of effective critical mass organization for cooperative learning and importance of group learning. To do this, different data were collected from different participants with different data collection tools. After the data collected, analyzed and discussed with major theme of the research, the researcher has found evidence to reach at the following conclusions.

Different challenges listed by different scholars were also found as major challenge in organizing and implementing effective critical mass organization for cooperative learning at Debremarkos College of teacher education.

Most challenges were listed similarly both student and teacher participants.

Most student participantswereresponded that effective critical mass organization is just only the task of teachers.

As all the data collected by FGD, questioners and documents analysis were found the same and big challenge of implementing the program were negative attitude of students and teachers towards the program.

Because of no uniform guide line for implementing the program as teachers and students think, it also obstacle the implementation of the program.

Most challenges driven from teachers, students and the college itself were affect the well implementation of the program.

Most of cleaver students were complaining about the disturbance of some carless students by playing music with their mobile.

Students need effective critical mass organization for only gaining mark by being dependent on others.

Having experienced advisor, each section has its own advisor, some students facilitating skill, assigning professional teachers as an advisor, writing a letter about advising for teachers formally, being agenda of discussion in academic commission and having enough space in the opposite shift were best opportunities found in the study area.

As the post hock data analysis portrayed, there were a notable difference on organizing and implementing effective critical mass organization between different departments[5.4 mean 
difference], students understanding[5.95 mean difference] and students attitude towards the program[6.08 mean difference].

The overall organization and implementation of effective critical mass were at grass root level in the study area.

Even if the teacher response show that effective critical mass is organized and implemented, the data collected from students, document analysis and FGD assured that even the program isn't started[ some students did not know who their advisor is]

\subsection{Recommendations}

The $21^{\text {st }}$ Century is the era when dynamic changes were occurring in all aspects of life and paradigm shifts in the philosophy of students learning (Animaw; 2012).Effective critical mass organization and implementation for cooperative learning is supported by different activists of cooperative learning theory like Jonson and Jonson. The study were aimed at assessing on challenges, opportunities and implementations of effective critical mass organization for cooperative learning at Deberemarkos college of teacher education. Due to this reason, data were collected with different appropriate data collection tools and analyzed with different techniques and major findings were drowning from the analysis. After these actions were completed the researcher draws the following recommendations with different bodies.

\subsubsection{For College students}

Now a day, cooperative learning is becoming the key instrument for best achievements of students. Therefore, students should understand why they are expected to learn and organize effective education critical mass in their class.

Students negative attitude towards the program were the predominant factor for the organizing and implementing effective education critical mass, students should arrange agenda at classroom level and discuss to solve the problem of attitude.

Cleaver students complaining about the disturbance of some student with opening music with their mobile, the class members should inform to the pre service or in service program case team workers or classroom advisors.

Students are expected to avoid dependency and aimed on effective critical mass for only gaining mark doing with clever students.

\subsubsection{For college Teachers}

College instructors are not only responsible for teaching their students but also they should lead their students towards the policy direction and guide in line with the need of the $21^{\text {st }} \mathrm{C}$. Team work is the golden acceptable element for achievement in education. Then, in order to become effective in this task, the teachers' strong participation is needed. Due to this reason, the following recommendations were forwarded for college teachers.

College teacher $(100 \%)$ respondents were responded that students were not interested at the formation of effective education critical mass in their class. This shows that teachers left their leading task in the program. Therefore, college teaches should have looked in ward and assists their students.

Teachers were believed that only letting students to organize themselves and inform about they are assigned as an advisor in some class is enough and consider as effective education critical mass organization. But the reality is vice versa. So at least, teachers should perform the task in which the college informs with the formal letter.

As the collected and analyzed data inferred, teachers were thinking about effective education critical mass is the task of politics so it should have leave to politician. One of effective education critical mass is one to five organizations and it is derived from Jonson and Jonson theory of cooperative learning. Then, teachers should have to related with the theory rather than wrongly associate with politics.Since there are many best opportunities in the college, teachers should use this best opportunities to promote organizing and implementing effective education critical mass for group learning which is supported by different scholars like Davis, Jonson and Jonson.

The implementation of effective education critical mass is to be found at grass root level. Teacher should understand and should have stood to go well for implementing the program.

\subsubsection{For College Administrative bodies and Academic commission}

The effective education critical mass is derived from the constructivist approach which needs cooperative learning and generating knowledge from the learners rather than considering the teacher is the only source of knowledge. Effective education critical mass organization is used as an umbrella for other kinds of learning. Since the implementation of organizing and implementing effective education critical mass is at unsatisfactory level; The College needs to accept the following recommendation recommended from the well analysis and finding from the study.

As the respondents responded that, there are no guide line prepared for organizing and implementing effective education critical mass for cooperative learning. Then, the college should communicate with the regional education office and prepare a guide line as a blue print for supporting to organizing and implementing effective education critical mass for cooperative learning.

From the finding of the study, most respondent students responded that performing the task is the obligation of teachers but not students. This shows that student's attitude isn't at the right track. To solve this problem the college should deal deeply with students.

The college should inform to students that the program planned for effective education critical mass should be considered as a regular class and attendance has its own value.

As document analysis and academic commission minute assured that there are some departments which are best performer in the activity of effective education critical mass, so the college should scale up likewise activities.

The college academic commission taken as an agenda about effective education critical mass organization and implementation in different departments and most department hrads speak about it implements well where us the data of document analysis found opposite to the department head sayings, the academic commission should have to designed mechanism of checking rather than believing only the report only.

The regional education bureau should collaborate with the college to implement effective education critical mass organization at college level. 
The concept of effective education critical mass theory should deal with college teachers deeply to avoid the gap of teachers who believed it is the task of politics.

Since teachers are complaining about that there are no guide line regarding with implementing effective education critical mass, the regional education bureau should prepare a guide line cooperate with the colleges

\section{REFERENCES}

[1] Beebe, S. A., \& Masterson, J. T. (2003).Communicating in small groups. Pearson

[2] Cohen, E. (1986). Designing groupwork: Strategies for the heterogeneous classroom.New York: Teachers College Press

[3] Blowers.(2000) constructivist model of mentoring, coaching, and facilitating online discussion. Distance course work? Australasian Journal of Educational Technology, 24(2), 195-210

[4] Cohen, E.G. (1994b).Restructuring the classroom: Conditions for productive small groups.Review of Educational Research, 64(1), 1-35.

[5] Cohen, E.G., (1994a).Designing groupwork: Strategies for the heterogeneous classroom (2nd Ed.). New York: Teachers College Press. constructivist model of mentoring, coaching, and facilitating online discussion. Distance course work? Australasian Journal of Educational Technology, 24(2), 195-210

[6] Csernica, J., Hanyka, M., Hyde, D., Shooter, S., Toole, M., \&Vigeant, M. (2002).Dahlerup, D. (1988) 'From a Small to a Large Minority:Women in Scandinavian Politics', Scandinavian Political Studies, 11 (4), 275-97.

[7] Dahlerup,D. and Freidenvall, L. (2005) 'Quotas as a "FastTrack" to Equal Political Representation forWomen: Why Scandinavia is No Longer the Model', InternationalFeminist Journal of Politics, 7 (1), 26-48

[8] Davis, B. G. (1993). Tools for Teaching.Jossey-Bass Inc., San Francisco: California.

[9] Davis, B. Tools for Teaching. San Francisco: JosseyBass, 1993. Education Inc. Boston: Massachusetts Education, 26(3) 341-366.

[10] Elgort, I., Smith, A. G., \&Toland, J. (2008). Is wiki an effective platform for group

[11] Fiese, R. K. \&DeCarbo, N. J. (1995). Urban music education: The teachers 'perspective.Music Educators Journal, 81(6), 27-31.

[12] Hardin, R. Collective action.Johns Hopkins University Press, 1982.http://mlkrook.org/pdf/childs_krook_2008.pdf

[13] Pamela Oliver, Critical Mass Theory. http://onlinelibrary.wiley.com/doi/10.1002/97804706748 71.wbespm059/abstract DOI: 10.1002/9780470674871.wbespm059

[14] Teaching for Meaningful Learning: A Review of Research on Inquiry-Based and Cooperative Learning By
Dr. Brigid Barron and Dr. Linda Darling-Hammond, Stanford University. http://www.edutopia.org/pdfs/ edutopia-teaching-for-meaningful-learning.pdf

[15] ML Markus, Toward a Critical Mass of Interactive Media. http://www.ee.oulu.fi/ vassilis/courses/socialweb 10F/reading_material/6_nonno/markus87-

Toward\%20a\%20Critical\%20Mass\%20Theory.pdf

[16] A Theory of the Critical Mass. I. Interdependence, Group Heterogeneity, and the Production of Collective Action. Pamela Oliver and Gerald Marwell. http://www.ssc.wisc.edu/ oliver/PROTESTS/ArticleCop ies/OliverMarwellCritMassI.pdf

[17] Whatever Happened to Critical Mass Theory? A Retrospective and Assessment*, Pamela E. Oliver and Gerald Marwell http://www.ssc.wisc.edu/ oliver/wp/wpcontent/uploads/2015/06/OliverMarwell2001SocTheory WhateverCritMass.pdf

[18] Robert E. Slavin, Co-Operative Learning: What Makes Groupwork Work? http://www.successforall.org/ successforall/media/pdfs/cl--what-makes-groupworkwork.pdf

[19] Postsecondary Peer Cooperative Learning Programs: Annotated Bibliography. Compiler/Editor: David R. Arendale http://www.tc.umn.edu/ arend011/Peerbib03 .pdf

[20] Richard M. Felder and Rebecca Brent, Cooperative Learning. http://www4.ncsu.edu/unity/lockers/users/f/ felder/public/Papers/CLChapter.pdf

[21] Critical mass (sociodynamics): https://en.wikipedia.org/wiki/Critical_mass_(sociodynam ics)

[22] Cooperative Learning Job Placards. Retrieved from Drumming to the Beat of a Different Marcher by Debbie Silver (Incentive Publications, 2005) https://www.asdk12.org/MiddleLink/Inter/mosaic/Coop_ Placards.pdf

[23] Johnson, D.W., \& Johnson, R.T. (1979). Conflict in the classroom: Controversy and learning. Review of Educational Research, 49, 51-70

[24] Johnson, D.W., \& Johnson, R.T. (1989). Cooperation and competition: Theory and research. Edina, MN: Interaction Book Co.

[25] Johnson, D.W., \& Johnson, R.T. (1992). Positive interdependence: Key to effective cooperation. In R. Hertz-

[26] Johnson, D.W., \& Johnson, R.T. (1994).Learning together and alone: Cooperative, competitive, and individualistic learning (4th Ed.). Boston: Allyn\& Bacon.

[27] Johnson, D.W., Maruyama, G., Johnson, R., Nelson, [18] D., \&Skon, L. (1981). Effects of cooperative, competitive, and individualistic goal structures on achievement: A meta-analysis. Psychological Bulletin, $89,47-62$ 
[28] Johnson, L.C. \& Waxman, H.C. (1985, March). Evaluating the effects of the "groups of four" program. Paper presented at the annual convention of the American Educational Research Association, Chicago.

[29] Johnson, L.C. (1985). The effects of the groups of four cooperative learning model on student problem-solving achievement in mathematics. Unpublished doctoral dissertation, University of Houston.

[30] Kanter, R. M. (1977a) 'Some Effects of Proportions on Group Life', American Journal of Sociology, 82 (5), 965-90.

[31] Kanter, R. M. (1977b) Men andWomen of the Corporation.NewYork: Basic Books.

[32] Lazarowitz\& N. Miller (Eds.), Interaction in cooperative groups: The theoretical anatomy of group learning (pp.
174-199). New York: Cambridge University Press Murphy, K. L., Mahoney, S. E., Chen, C. Y., [25[

[33] Mendoza-Diaz, N. V. \& Yang, X. (2005). A Oliver, P., Marwell, G. and Teixeira, R. A theory of the critical mass. I. Interdependence, groupheterogeneit

[34] Olson, M. The logic of collective action: Public goods and the theory of groups. Harvard UnivPr, 1971.Practical guide to teamwork, version 1.1.College of Engineering, Bucknell University.

[35] Slavin, R.E., N.L. Karweit, and N.A. Madden, Effective Programs for Students at Risk, Allyn and Bacon, Boston, 1989.

[36] Wasley, P. (November 17, 2006). Underrepresented students benefit most from 'engagement.' The Chronicle of Higher Education, 53 (13), p.A39 